\title{
ASPECTOS MACROSCÓPICOS E MORFOMÉTRICOS DOS TESTÍCULOS EM CATETOS E QUEIXADAS
}

\author{
Jussara Barreira Sonner ${ }^{1}$; Maria Angélica Miglino²; Tatiana Carlesso dos Santos ${ }^{3}$; Roberto Carvalhal ; Antônio \\ Chaves de Assis Neto ${ }^{4}$ Carlos Eduardo Bezerra de Moura ${ }^{2}$; Moacir Franco de Oliveira ${ }^{6}$.
}

Biota Neotropica v4 (n2) - http://www.biotaneotropica.org.br/v4n2/pt/abstract?article+BN03004022004

Recebido em: 08/03/2004 - Revisado em: 29/07/2004 - Publicado em: 10/08/2004

\begin{abstract}
${ }^{1}$ Graduanda em Medicina Veterinária da Universidade de Guarulhos, Guarulhos, SP. Iniciação Científica vinculada ao Projeto BIOTA/FAPESP. ${ }^{2}$ Faculdade de Medicina Veterinária e Zootecnia, USP, SP. ${ }^{3}$ Centro Regional Universitário de Espírito Santo do Pinhal,SP. ${ }^{4}$ Faculdade de Zootecnia, UNESP, Unidade Diferenciada de Dracena, SP. ${ }^{5}$ Medicina Veterinária, UNESP, Campus Araçatuba, SP. ${ }^{6}$ Escola Superior de Agricultura de Mossoró, Mossoró, RN. Correspondência para:Profa. Dra. Maria Angelica Miglino, Av. Prof. Dr. Orlando Marques de Paiva, 87, Cidade Universitária Armando de Salles Oliveira, 05508-000 miglino@usp.br
\end{abstract}

\begin{abstract}
Macroscopic and morphometric features of testicles in collared peccary and white-lipped peccary.

This work aims to describe the morphometrical aspects on the testicles of the collared peccary and white-lipped peccary. The material derived from the Devaneio Pro-Fauna Farm, Iguape, SP (Reg.1/3593/08480). From 33 white-lipped peccary and 20 collared peccary after the slaughter, the testicles were removed and morphometric information was taken like: length, width and thickness (with the help of a pachymeter). Testicles are oval shaped, located into the pelvic region, laying dorsocaudally and they have intermediary position. The mediastinun testis is in the center of the testis and ends on the capitata extremity. The adult white-lipped peccary has $30.92 \pm 3.82 \mathrm{~kg}$ in average and $78.89 \pm 4.77 \mathrm{~cm}$ of length and the young has $22.93 \pm 2.07 \mathrm{~kg}$ and $71.57 \pm 3.95 \mathrm{~cm}$ of length. Results obtained show that in the adult white-lipped peccary group, the right testicle measured, in average, length, width and thickness of $5.36 \pm 0.64 \mathrm{~cm}, 3.64 \pm 0.64 \mathrm{~cm}$ and $3.30 \pm 0.52 \mathrm{~cm}$ respectively while the left testicles measured, in average, $5.45 \pm 0.77 \mathrm{~cm}, 3.68 \pm 0.59 \mathrm{~cm}$ and $3.32 \pm 0.54 \mathrm{~cm}$. In the young group the testis measured in average $3.20 \pm 0.44 \mathrm{~cm}, 2.12 \pm 0.26 \mathrm{~cm}$ and $2.11 \pm 0.40 \mathrm{~cm}$, to right testis and $3.23 \pm 0.47 \mathrm{~cm}, 2.21 \pm 0.39 \mathrm{~cm}$ and 1.99 $\pm 0.36 \mathrm{~cm}$, to left testis, to length, width and thickness, respectively. As per the collared peccary, the right testicles measured, in average, $4.36 \pm 0.38 \mathrm{~cm} ; 2.74 \pm 0.27 \mathrm{~cm}$ and $2.33 \pm 0.46 \mathrm{~cm}$ respectively for length, width and thickness, when for the left ones measures were $4.19 \pm 0.36 \mathrm{~cm}, 2.68 \pm 0.31 \mathrm{~cm}$ and $2.34 \pm 0.28 \mathrm{~cm}$. The data does not have significative difference $(p<0.05)$ between right and left testicular measurements using the Qui-square test.
\end{abstract}

Key words: collared peccary, white-lipped peccary, testicles, genitals, Tayassu.

\section{Resumo}

Aspectos macroscópicos e morfométricos dos testículos em catetos e queixadas.

Este trabalho objetiva fornecer dados macroscópicos e morfométricos dos testículos dos catetos e queixadas. O material utilizado consistiu de catetos e queixadas oriundos da Fazenda Devaneio Pró-Fauna, Iguape, SP (Reg.1/3593/08480). Em 33 queixadas e 20 catetos, após o abate, os testículos foram colhidos e tomados dados morfométricos como: comprimento, largura e espessura (com o auxílio de um paquímetro). Os testículos são ovalados, localizados na região pélvica, inclinados dorso-caudalmente e possuem posição intermediária. O mediastino testicular esta no centro do testículo, ligeiramente desviado para a margem epididimária deste, e termina na extremidade capitata. Os queixadas adultos possuem em média $30,92 \pm 3,82 \mathrm{~kg}$ de peso corporal e $78,89 \pm 4,77 \mathrm{~cm}$ de comprimento corporal, enquanto os jovens apresentam 22,93 $\pm 2,07 \mathrm{~kg}$ e 71,57 $\pm 3,95 \mathrm{~cm}$ de comprimento. Os resultados demonstram que no grupo de queixadas adultos estudado o testículo direito teve comprimento, largura e espessura médios de $5,36 \pm 0,64 \mathrm{~cm} ; 3,64 \pm 0,64 \mathrm{~cm} \mathrm{e} 3,30 \pm 0,52 \mathrm{~cm}$ respectivamente, enquanto que o esquerdo teve $5,45 \pm 0,77 \mathrm{~cm} ; 3,68 \pm 0,59 \mathrm{~cm}$ e $3,32 \pm 0,54 \mathrm{~cm}$. Nos queixadas jovens os valores encontrados foram de $3,20 \pm 0,44 \mathrm{~cm}, 2,12 \pm 0,26 \mathrm{~cm}$ e $2,11 \pm 0,40 \mathrm{~cm}$, e de $3,23 \pm 0,47 \mathrm{~cm} ; 2,21 \pm 0,39 \mathrm{~cm} \mathrm{e} 1,99 \pm 0,36 \mathrm{~cm}$, para a largura, comprimento e espessura dos testículos direito e esquerdo respectivamente. Já para os catetos o testículo direito teve comprimento, largura e espessura de $4,36 \pm 0,38 \mathrm{~cm} ; 2,74 \pm 0,27 \mathrm{~cm}$ e $2,330,46 \mathrm{~cm}$ respectivamente, enquanto que o esquerdo teve $4,19 \pm 0,36 \mathrm{~cm} ; 2,68 \pm 0,31 \mathrm{~cm}$ e $2,34 \pm 0,28 \mathrm{~cm}$. Os dados analisados não tiveram diferenças significativas $(\mathrm{p}<0,05)$ entre os valores encontrados para os testículos direito e esquerdo pelo testes de Qui-dradado.

Palavras-chave: cateto, queixada, testículo, genital, Tayassu. 


\section{Introdução}

O cateto (Tayassu tajacu Linnaeus, 1758) e o queixada (Tayassu pecari Link, 1795) são conhecidos popularmente como porcos-do-mato e distribuem-se desde o sul dos Estados Unidos da América até o sul da Argentina. Ambos pertencem à ordem Artiodáctila, à Sub-ordem Nonruminantia, Superfamília Suoidea e à Família Tayassuidae (Schimidt 1988, Nowak 1991). Compõe ainda essa família um segundo gênero, o Catagonus wagneri Rusconi 1930, considerado extinto até recentemente quando uma população foi redescoberta na região conhecida como Grande Chaco, no Paraguai (Vaughan 1978).

O cateto possui pelagem cinza escuro e caracterizase pela presença de uma faixa de pêlos brancos ao redor do pescoço. O comprimento corporal varia de 75 a $100 \mathrm{~cm}$ e o peso corporal de 14 a $30 \mathrm{~kg}$. Já o queixada é proporcionalmente maior que o cateto, possuindo comprimento corporal de 95 a $110 \mathrm{~cm}$ e peso de 31 a $43 \mathrm{~kg}$. Caracteriza-se pela presença de pêlos esbranquiçados na região submandibular e no início do pescoço (Nowak 1991).

A fisiologia reprodutiva do cateto e do queixada é semelhante àquela dos suínos domésticos. Estes se acasalam durante todas as épocas do ano e normalmente nascem de 2 a 3 filhotes, em cada gestação. Tanto o cateto quanto o queixada atingem maturidade sexual com 10 meses de idade (Sowls 1984, Sowls 1961 e Wislocki 1931).

Hellgren et al. (1989) citam que as concentrações séricas de testosterona e as mensurações testiculares de catetos machos adultos variam em uma baixa amplitude no modelo circanual, com médias máximas de concentração de testosterona no outono e inverno (1150-1400pg/ml), no entanto, as características do sêmen não apresentam essas variações.

O comportamento reprodutivo destes animais por muito tempo foi desconhecido. A criação desses animais em cativeiro possibilitou observações a respeito da época de nascimento, comprimento e freqüência do ciclo estral, período de gestação e idade de nascimento. Esses dados indicaram um alto potencial na capacidade reprodutiva das espécies (Sowls 1961).

Aliado ao surgimento de dados que permitem a criação destes animais, o aumento do consumo de carnes de animais silvestres vem estimulando o surgimento de criatórios que visam a exploração zootécnica destas espécies. Como o caso do Centro de Multiplicação de Animais Silvestres-Mossoró, RN, onde os animais são criados para fins de pesquisa. Neste centro observou-se, por exemplo, que uma relação de 3 machos para nove fêmeas, mostram melhor rendimento reprodutivos (Oliveira et al. 2001).

A presente pesquisa fundamenta-se na necessidade de informações que possam subsidiar outras, principalmente na área de reprodução animal, com o objetivo de preservação das espécies e aproveitamento controlado e racional das mesmas.

\section{Material e Método}

O material obtido consistiu-se de 20 catetos e 33 queixadas machos, abatidos na Fazenda Devaneio-PróFauna, Iguape-SP (registro 1/3593/08480), os quais foram oriundos de diferentes criatórios.

Após o abate, os testículos foram colhidos e tomados dados morfométricos como: comprimento (da extremidade capitata a extremidade caudata), largura (da margem livre a margem epididimária) e espessura (da face lateral a face medial do testículo), com auxílio de um paquímetro. Particularmente nos queixadas, além dos dados biométricos referentes aos testículos, mensurou-se o comprimento corporal (da articulação atlanto-occipital à base da cauda) e o peso corporal dos animais.

Os testículos foram então fixados em solução de formalina a $10 \%$ e posteriormente dissecados para descrição macroscópica. Para a análise histológica, colheram-se fragmentos de 05 catetos e 8 queixadas (04 adultos e 04 jovens), os quais foram fixados em formalina $10 \% \mathrm{e}$ processados na rotina histológica, corando-se as lâminas obtidas em HE e tricrômio de Masson.

Os dados obtidos dos queixadas abatidos (novembro de 2001 e abril de 2003) foram separados em animais adultos e jovens, e o critério utilizado para tal foi o comprimento dos testículos. Animais que apresentaram testículos com comprimento maior que $4 \mathrm{~cm}$ foram considerados adultos e animais com testículos menores que $4 \mathrm{~cm}$ foram considerados jovens. A comprovação deste dois grupos foi obtida pela análise dos resultados histológicos em que se avaliou a formação dos túbulos seminíferos. Os catetos (novembro de 2001) cujos dados biométricos foram analisados eram todos adultos.

As descrições sobre a posição anatômica dos testículos nos catetos e queixadas foram realizadas por observações a campo e confirmadas pela dissecação de 02 animais fixados em formalina $10 \%$, animais estes pertencentes ao acervo de peças anatômicas do Laboratório de Anatomia dos Animais Domésticos e Silvestres, da FMVZ-USP.

Os dados biométricos obtidos, tanto em catetos quanto em queixadas, foram analisados estatisticamente pelo programa BIO ESTAT 3.0 (Ayres et al., 2003).

Todos os procedimentos realizados foram documentados por fotografias, fotomicrografias e os termos adotados estão baseados na Nomina Anatomica Veterinaria (International Committee on Veterinary Gross Anatomical Nomenclature 1994).

\section{Resultados}




\subsection{Aspectos morfológicos dos testículos}

Os catetos e os queixadas são suiformes e possuem morfologia reprodutiva semelhante ao dos demais suídeos. Nos pecaris o escroto localiza-se ventralmente ao ânus, projetando-se na superfície corporal, contornando os órgãos que contém, testículos e epidídimos (Fig. 1). A pele do escroto apresenta pigmentação, como no restante do corpo, porém está desprovida dos pêlos típicos dos Tayassuideos, caracteristicamente longos e espessos, possuindo apenas alguns pêlos mais delicados.

Quando o animal jovens é suspenso pelos membros pélvicos, os testículos "desaparecem" sob a pele e sua identificação é possível pela palpação e pela pele modificada do escroto. Esta característica é tão mais evidente quanto mais jovem for o animal.

Em estação, os testículos projetam-se caudalmente na superfície corporal, são facilmente distinguíveis sob o escroto e a rafe testicular é profunda, separando o escroto em duas lojas testiculares bem pronunciadas (Fig. 1).

O escroto contendo os testículos nos pecaris está localizado na região pélvica e possui posição intermediária (entre a perineal e a inguinal), de modo que o eixo maior dos testículos inclina-se dorso-caudalmente. Desta forma a extremidade capitata dos testículos, juntamente com a cabeça do epidídimo, localiza-se ventro-cranialmente e a extremidade caudata dos testículos, juntamente com a cauda do epidídimo, posiciona-se dorso-caudalmente em relação ao corpo do animal (Fig. 2).

Os testículos dos pecaris encontram-se envoltos por uma fáscia espermática fibrosa, extremamente resistente, possuem forma ovalada, com duas margens e duas extremidades e são achatados latero-lateralmente. A margem livre dos testículos volta-se lateralmente, enquanto a epididimária mantém relações com o epidídimo medialmente. Os testículos possuem ainda duas extremidades a capitata, onde se inicia o epidídimo, e a caudata, onde o epidídimo origina o ducto deferente. $\mathrm{Na}$ extremidade capitata do testículo encontra-se o funículo espermático (Fig. 3a), que por sua vez contém as estruturas que se destinam (artérias) e que partem (ducto deferente, veias, linfáticos) do epidídimo e do testículo, além dos nervos, do músculo cremáster e da túnica vaginal. Nos animais estudados o m. cremáster é desenvolvido, originando-se de feixes de músculos abdominais (Fig. 2).

Ao abrir a fáscia espermática encontramos os testículos revestidos pela túnica albugínea (cápsula), que esta recoberta externamente pela lâmina visceral da túnica vaginal. A túnica albugínea consiste de uma espessa camada de tecido conjuntivo denso modelado, rica em fibras colágenas arranjadas circularmente em relação ao eixo maior dos testículos, e por um estrato vascular, com vasos sanguíneos flexuosos provenientes da artéria testicular, os quais nos catetos e queixadas analisados dispõem-se na região mais próxima ao parênquima testicular (Fig. 3b).

No pólo cranial do testículo a túnica albugínea é contínua com o tecido conjuntivo frouxo do mediastino testicular, o qual envolve a rede testicular. A partir da abugínea partem septos de tecido conjuntivo em direção ao centro do testículo (Fig. 3c, 3d), dividindo o parênquima testicular em lóbulos testiculares, os quais encontram-se preenchidos pelo parênquima testicular. Estes septos fornecem ao testículo um arcabouço fibroso para sustentação dos túbulos seminíferos e ductos.

$\mathrm{Na}$ região esbranquiçada do mediastino testicular encontramos a rede testicular, que por sua vez é axial e esta orientada em direção a extremidade capitata do testículo. Tanto no cateto quanto no queixada a rede testicular localizase na região central do órgão, posiciona-se mais próxima a margem epididimária e ocupa cerca de dois terços do comprimento do testículo (Fig. 3c, 3d).

Quando se analisa os testículos macroscopicamente é possível observar a natureza enovelada dos túbulos seminíferos, os quais se direcionam para o mediastino (Fig. 4a e 4b). A análise histológica dos dois grupos de queixadas, separados em função do comprimento testicular, confirmou que animais com testículos cujo comprimento testicular é menor que $4 \mathrm{~cm}$ apresentam morfologia distinta daqueles com testículos maiores que $4 \mathrm{~cm}$, diferenciando-os entre adultos e jovens.

Histologicamente o parênquima testicular dos catetos e queixadas está constituído por um compartimento tubular, onde encontram-se os túbulos seminíferos nos animais adultos e os cordões testiculares nos animais jovens impúberes (Fig. 4c e 4d), e por compartimento intertubular, onde se encontram as células de Leydig, tecido conjuntivo e vasos sanguíneos. Os túbulos seminíferos dos catetos e queixadas tornam-se menos contorcidos a medida que se aproximam do mediastino testicular, assumem um trajeto quase reto e continuam-se pelos túbulos retos, na rede testicular.

Nos testículos daqueles queixadas considerados jovens, possivelmente em período impúbere, os túbulos seminíferos ainda não estão formados e em seu lugar há cordões testiculares, caracterizados pela ausência de luz no tubo e duas populações celulares, os gonócitos e as células de suporte.

Os jovens possuem ainda muito mais tecido intercordonal que nos adultos, com grande concentração de células de Leydig. Apesar da relação entre estas duas regiões não ter sido estabelecida por meio de uma análise histométrica do parênquima testicular, a diferença é facilmente observável quando se compara qualitativamente os cortes histológicos de ambas as idades reprodutivas sugeridas (Fig. 4c, 4d).

As células de Leydig distinguem-se facilmente das demais células encontradas no conjuntivo frouxo da região 
Figura 01 - Fotografias de queixadas (la e 1b) e catetos (1c e 1d) evidenciando a posição dos testículos, os quais se encontram dentro do escroto (E). Notar a rafe testicular pronunciada (seta).

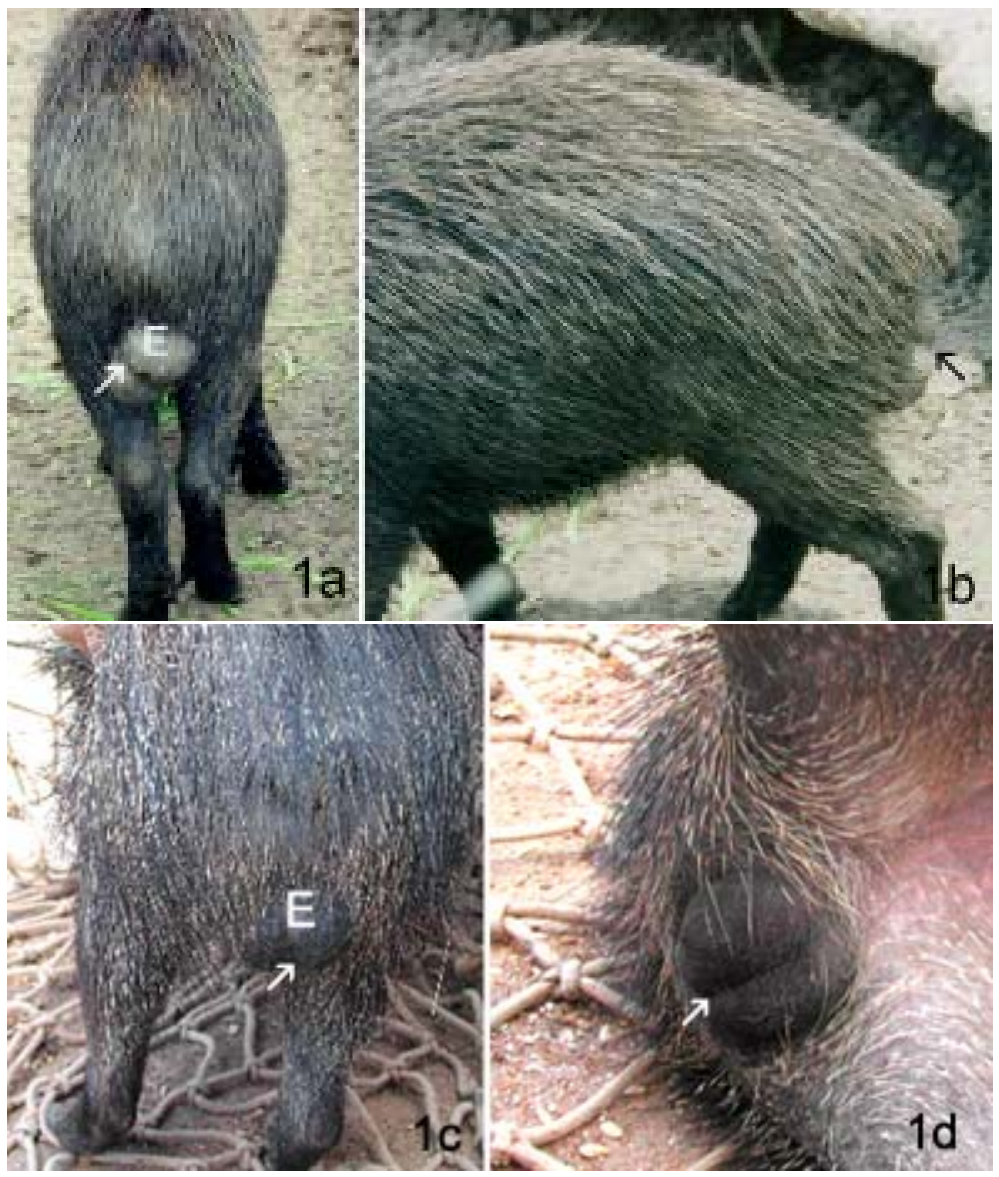

http://www.biotaneotropica.org.br 
Figura 02 - Fotografia de queixada adulto fixado em formol, dissecado pela face lateral esquerda (membro pélvico esquerdo retirado) para visualização dos órgãos genitais. Notar a posição perineal e inclinada dos testículos (T) e a formação do músculo cremáster (MC) a partir de músculo abdominal. Ab-abdome, L - linfonodo, $P$ - pelve.

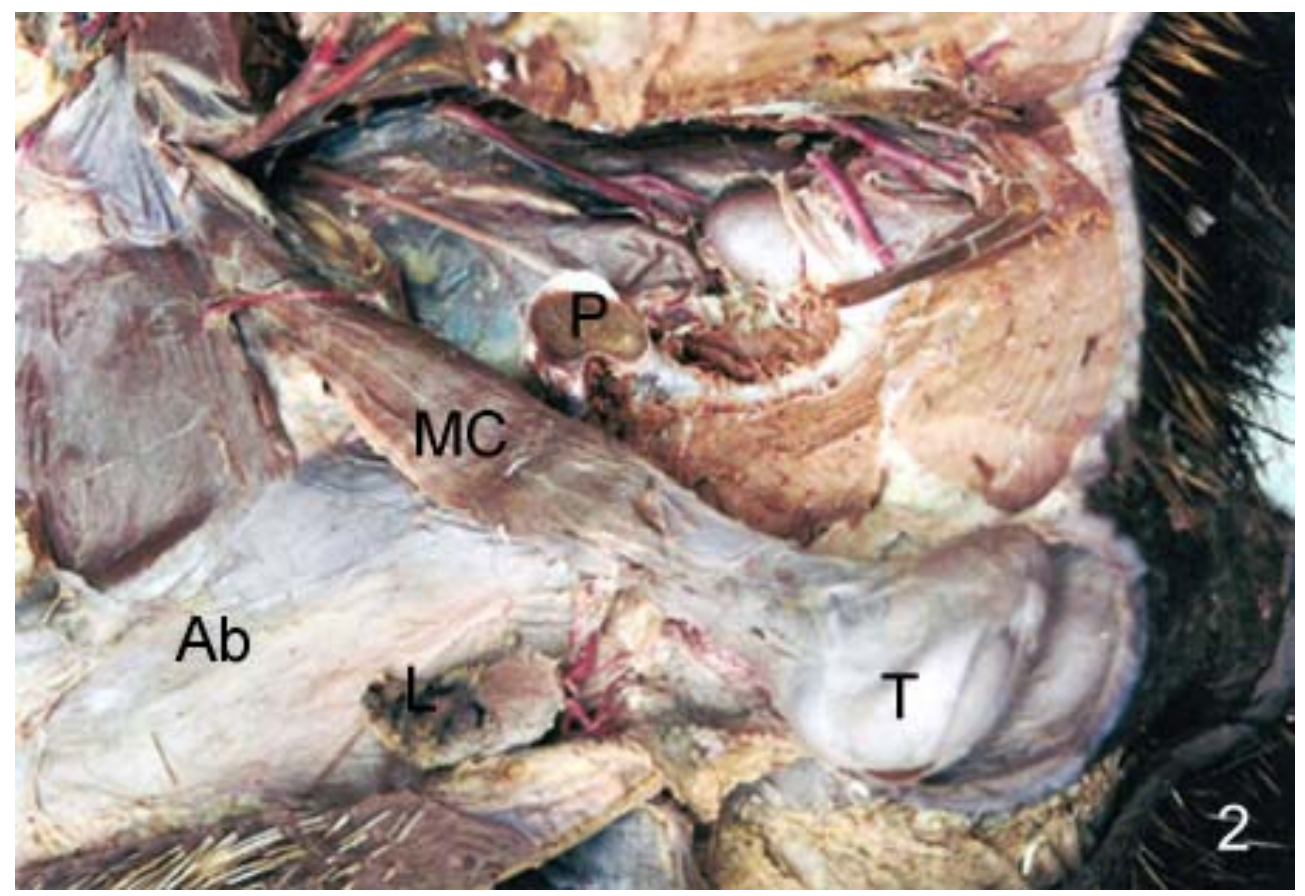


Figura $03-a, c, d)$ Fotografias de testiculos de queixada adulto vistos lateralmente (3a), em corte transversal (3c) e longitudinal (3d). Observar a relação do testículo (T) com o epidídimo (EP) e com o funículo espermático (FE). A túnica albugínea ou cápsula testicular (C) envia septos (S) para o parênquima do testículo, dividindo-o em lóbulos (L) e o mediastino testicular (M) dirige-se ao pólo cranial do testículo (*). b) Fotomicrografia de corte histológico de testículo de queixada jovem evidenciando a túnica albugínea. Notar a disposição do tecido conjuntivo denso modelado (TC) e do estrato vascular (V). Paraplast, HE.
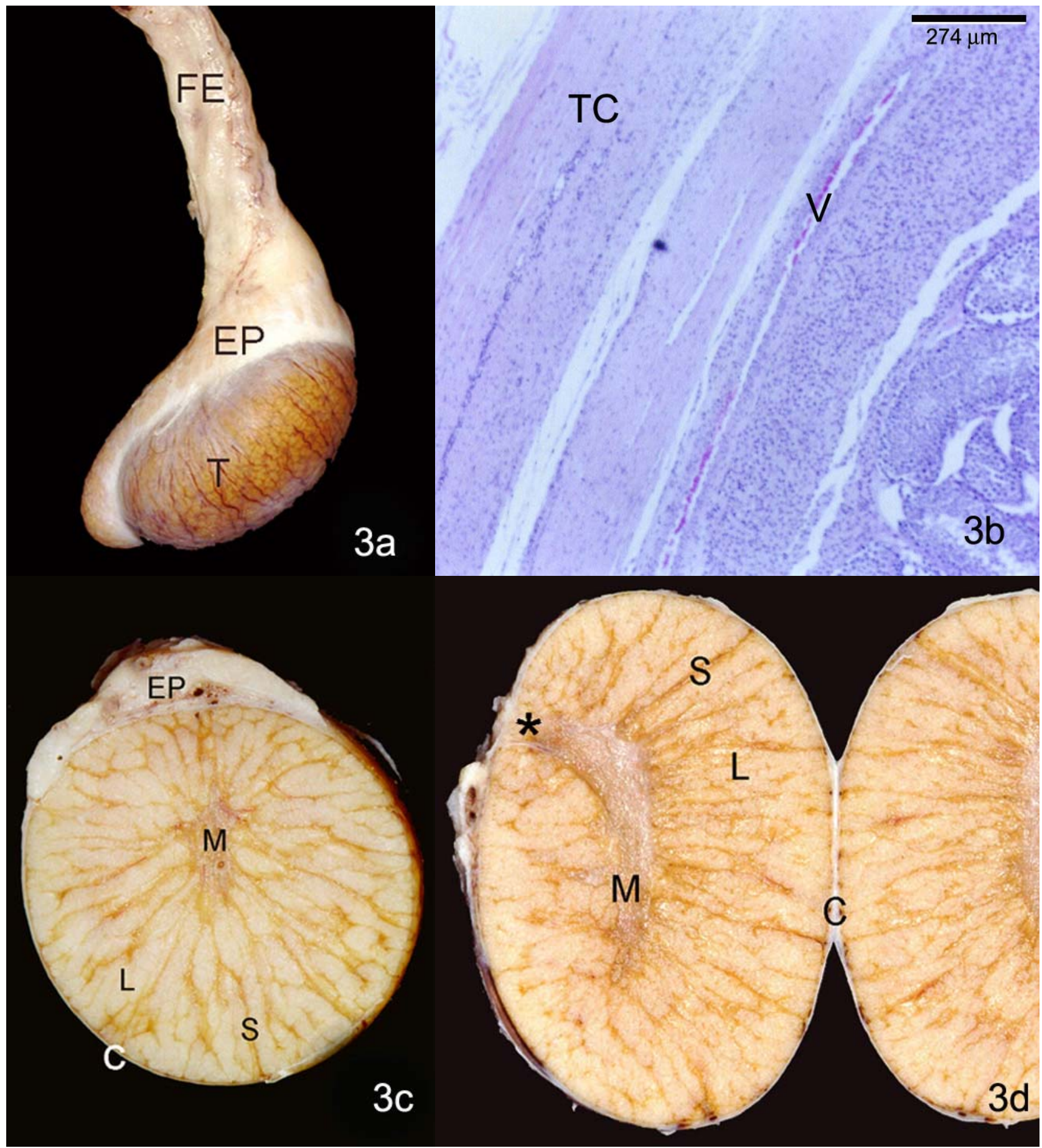

http://www.biotaneotropica.org.br 
Figura 04. a-b) Fotografias de testículo de queixada adulto fixado em formol, demonstrando a formação enovelada dos túbulos seminiferos (TS) encaminhando-se para os túbulos retos da rede testicular (RT), localizados no mediastino testicular. c-d) Fotomicrografias de parênquima testicular de queixada adulto (4c) e jovem (4d). No adulto evidencia-se o epitélio germinativo desenvolvido com espermatogônias (Eg), espermatócitos em fase de paquiteno (P), espermátides arredondadas (E), espermátides alongadas (Es) voltadas para a luz (L), e no jovem os cordões testiculares não luminados (TS) e grande quantidade de células de Leydig (Le) no tecido intersticial. e-f) Fotomicrografias de parênquima testicular de cateto adulto. Os túbulos seminiferos (TS) desembocam nos túbulos retos (TR), os quais estão revestidos por um epitélio cúbico (seta). Paraplast, HE (c,d,e) e tricrômio de Masson (f).

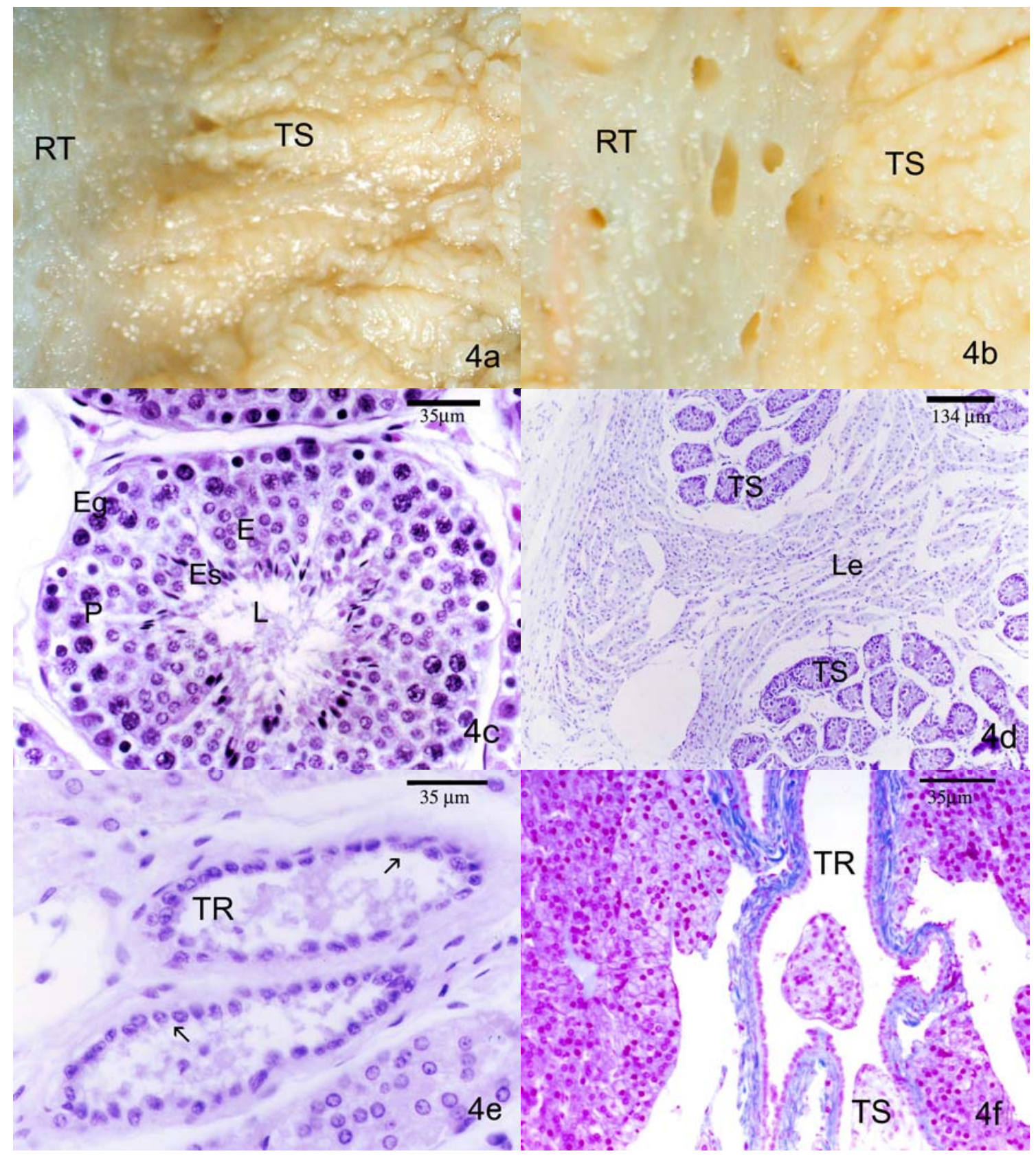

http://www.biotaneotropica.org.br 
Tabela 01 - Valores referentes ao comprimento e peso corporais de 07 queixadas jovens e 18 adultos. Iguape, SP, 2004.

\begin{tabular}{c|cccc}
\hline \multirow{2}{*}{ Sumário estatístico } & \multicolumn{2}{|c}{ jovens } & \multicolumn{2}{c}{ adultos } \\
& Peso & Comprimento & Peso & Comprimento \\
\hline Média & $22,93 \pm 2,07$ & $71,57 \pm 3,95$ & $30,92 \pm 3,82$ & $78,89 \pm 4,77$ \\
Mediana & 23,00 & 72,00 & 31,75 & 78,00 \\
Mínimo & 20,00 & 67,00 & 24,00 & 73,00 \\
Máximo & 25,00 & 78,00 & 37,00 & 77,00 \\
Variância & 4,2857 & 15,6190 & 14,6544 & 22,8105 \\
\hline
\end{tabular}

Tabela 02 - Dados biométricos referentes ao comprimento, largura e espessura do testículo de 11 queixadas jovens. Iguape -SP, 2004.

\begin{tabular}{c|ccccccc}
\hline & \multicolumn{3}{|c}{ Testículo direito } & \multicolumn{3}{c}{ Testículo esquerdo } \\
Sumário estatístico & comprimento & largura & espessura & comprimento & largura & espessura \\
& & & & & & \\
\hline Média & $3,20 \pm 0,44$ & $2,12 \pm 0,26$ & $2,11 \pm 0,40$ & $3,23 \pm 0,47$ & $2,21 \pm 0,39$ & $1,99 \pm 0,36$ \\
Mediana & 3,20 & 2,00 & 2,10 & 3,10 & 2,30 & 1,90 \\
Mínimo & 2,50 & 1,80 & 1,60 & 4,00 & 2,80 & 2,70 \\
Máximo & 3,90 & 2,70 & 2,80 & 2,50 & 1,60 & 1,50 \\
Variância & 0,1940 & 0,0676 & 0,1649 & 0,2262 & 0,1549 & 0,1329 \\
\hline
\end{tabular}


Tabela 03 - Dados biométricos referentes ao comprimento, largura e espessura do testículo de 21 queixadas adultos. Iguape, SP, 2004.

\begin{tabular}{c|ccccccc}
\hline & \multicolumn{3}{|c}{ Testículo direito } & \multicolumn{3}{c}{ Testículo esquerdo } \\
Sumário estatístico & comprimento & largura & espessura & comprimento & largura & espessura \\
\hline Média & $5,36 \pm 0,64$ & $3,64 \pm 0,64$ & $3,30 \pm 0,52$ & $5,45 \pm 0,77$ & $3,68 \pm 0,59$ & $3,32 \pm 0,54$ \\
Mediana & 5,4 & 3,8 & 3,3 & 5,5 & 3,6 & 3,3 \\
Mínimo & 4,2 & 2 & 1,8 & 3,8 & 2,4 & 1,9 \\
Máximo & 6,3 & 4,5 & 4,4 & 6,5 & 4,5 & 4,4 \\
Variância & 0,4175 & 0,4105 & 0,2710 & 0,6076 & 0,3599 & 0,2929 \\
\hline
\end{tabular}

Tabela 04 - Dados biométricos referentes ao comprimento, largura e espessura dos testículos de 20 catetos adultos. Iguape - SP, 2004.

\begin{tabular}{c|cccccc}
\hline & \multicolumn{3}{|c}{ Testículo Direito } & \multicolumn{3}{c}{ Testículo Esquerdo } \\
& Comprimento & Largura & Espessura & Comprimento & Largura & Espessura \\
\hline Média & $4,36 \pm 0,38$ & $2,74 \pm 0,27$ & $2,33 \pm 0,46$ & $4,19 \pm 0,36$ & $2,68 \pm 0,31$ & $2,34 \pm 0,28$ \\
Mediana & 4,4 & 2,75 & 2,3 & 4,25 & 2,8 & 2,35 \\
Mínimo & 3,7 & 2,0 & 1,9 & 3,2 & 1,9 & 1,8 \\
Máximo & 5,0 & 3,2 & 2,8 & 5,2 & 3,2 & 2,8 \\
Variância & 0.1498 & 0.0761 & 0.0412 & 0.2167 & 0.1329 & 0.0795 \\
\hline
\end{tabular}


intertubular pelo formato normalmente triangular ou poliédrico, e pelo grande núcleo arredondado, com cromatina frouxa. Observaram-se ainda vacúolos no citoplasma altamente eosinófilo sugestivos de acúmulos lipídicos.

Nos adultos os túbulos seminíferos dos machos consistem em uma túnica de tecido conjuntivo, uma lâmina basal e uma camada interna formada por um epitélio germinativo ou seminífero. Este apresenta células em diferentes graus de associação celular e próximo a lâmina basal encontram-se células isoladas de sustentação, denominadas de células de Sertoli.

No epitélio germinativo as espermatogônias são facilmente reconhecidas pelo grande citoplasma e núcleo. Já as espermátides possuem núcleos menores, mais condensados e menos granulados e os espermatozóides possuem forma alongada e núcleo condensado e estão localizados na luz do túbulo seminífero (Fig. 4d).

Os túbulos seminíferos desembocam nos túbulos retos, os quais se anastomosam em rede na rede testicular. Os túbulos retos estão revestidos por epitélio cúbico simples (Fig. 4e, 4f), com células mióides ao seu redor e encontramse entremeados por tecido conjuntivo frouxo, ricamente vascularizado. A rede testicular une-se ao epidídimo através dos ductos eferentes dispostos na extremidade capitata do testículo.

\subsection{Aspectos morfométricos dos testículos}

Os dados referentes aos queixadas foram agrupados em função do tamanho testicular, e as informações colhidas de todos os abates foram dividas em animais considerados adultos (21 animais) e animais considerados jovens (11 animais).

Com relação aos dados biométricos referentes a peso e comprimento corporal médios, os queixadas jovens apresentaram $22,93 \pm 2,07 \mathrm{~kg}$ e $71,57 \pm 3,95 \mathrm{~cm}$, e os adultos

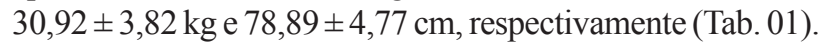

Os queixadas jovens apresentaram dados biométricos médios para o comprimento, largura e diâmetro do testículo direito de $3,20 \pm 0,44 \mathrm{~cm}, 2,12 \pm 0,26 \mathrm{~cm}$ e $2,11 \pm 0,40 \mathrm{~cm}$, respectivamente, enquanto o esquerdo teve $3,23 \pm 0,47 \mathrm{~cm}$; 2,21 $\pm 0,39 \mathrm{~cm}$ e $1,99 \pm 0,36 \mathrm{~cm}$, respectivamente (Tab. 2).

Já no grupo de queixadas adultos o testículo direito apresentou valores médios para comprimento, largura e diâmetro de $5,36 \pm 0,64 \mathrm{~cm} ; 3,64 \pm 0,64 \mathrm{~cm}$ e $3,30 \pm 0,52 \mathrm{~cm} \mathrm{e}$ para o testículo esquerdo de $5,45 \pm 0,77 \mathrm{~cm} ; 3,68 \pm 0,59 \mathrm{~cm}$ e $3,32 \pm 0,54 \mathrm{~cm}$, respectivamente (Tab. 3).

Os catetos analisados apresentaram testículo direito com $\pm 4,36 \pm 0,38 \mathrm{~cm} ; 2,74 \pm 0,27 \mathrm{~cm}$ e $2,330,46 \mathrm{~cm}$ e testículo esquerdo com 4,19 $\pm 0,36 \mathrm{~cm} ; 2,68 \pm 0,31 \mathrm{~cm}$ e $2,34 \pm 0,28 \mathrm{~cm}$ para comprimento, largura e espessura, respectivamente (Tab 4).

O teste de correlação de Pearson (r) aplicado aos dados biométricos obtidos nos catetos e queixadas demonstrou haver correlação:

-alta e positiva: entre o comprimento dos testículos direito e esquerdo $(\mathrm{r}=0,80$ para queixadas adultos, $\mathrm{r}=0,95$ para queixadas jovens),

-média e positiva: entre o comprimento dos testículos direito e esquerdo $(\mathrm{r}=0,66$ catetos adultos), entre o comprimento corporal e o comprimento dos testículos direito $(r=0,34)$ e esquerdo $(r=0,33)$ em queixadas jovens.

baixa e negativa: entre o comprimento corporal e comprimento dos testículos direito $(\mathrm{r}=-0,24)$ e esquerdo $(\mathrm{r}=$ $0,33)$ para queixadas adultos,

Os testes de Qui-quadrado não mostram diferenças significativas $(\mathrm{p}<0,05)$ quando comparados os valores encontrados nos testículos direito e esquerdo dos queixadas jovens, adultos e catetos, entre os parâmetros comprimento, largura e espessura dos testículos.

\section{Discussão}

Apesar dos catetos e queixadas serem mencionados muitas vezes como porcos-do-mato ou porcos selvagens (wild pigs) eles não são suínos verdadeiros, mas sim possuem um ancestral comum com estes, colocando-os lado a lado na Superfamília Suoidea (Carroll 1988, Sowls 1984). As estimativas baseadas em seqüências de DNA do citocromo mitocondrial b sugerem que estas duas famílias, Suidae e Tayassuidae, divergiram uma da outra a mais ou menos 33-37 milhões de anos atrás e que há fortes indícios de que o cateto e o queixada pertençam a gêneros diferentes (Theimer \& Keim, 1998).

Com algumas espécies já extintas e três vivendo nos dias atuais os tayassuideos mantiveram muitas semelhanças com os suínos do velho mundo ao longo dos processos evolutivos. Particularmente sobre o trato reprodutor Low (1970) comenta que nos machos há muita similaridade entre os catetos e os suínos domésticos. Já nas fêmeas Wislocki (1931) e Santos et al. (1999) citam que os órgãos reprodutivos possuem diferenças quando se comparam as espécies.

Os catetos $(2 n=30)$ e os queixadas $(2 n=26)$ podem produzir híbridos $(2 \mathrm{n}=28)$, no entanto estes são inférteis e nos machos, por exemplo, há formação dos túbulos seminíferos, os machos possuem libido mas são completamente inférteis (Andrea et al. 2001).

Nos animais estudados o escroto contendo os testículos possui posição intermediária e desta forma posiciona-se mais ventralmente que nos suínos domésticos (Barone 1990, Dyce et al. 1997). Este fato pode ser justificado pela grande curvatura dorsal que a coluna vertebral destes animais apresenta, posicionando o próprio ânus em uma situação mais ventral. Esta posição permite que o eixo maior do testículo incline-se, e assim também é nos suínos. 
As descrições macroscópicas de forma e posição realizadas nos catetos conferem com aquelas descritas anteriormente por Sowls (1984) e Carvalhal et al. (2000) e não há citações da morfologia nos queixadas que possam ser analisadas.

Particularmente nos catetos (Machado et al. 1997), descreve-se que o músculo cremáster termina na fáscia espermática, bem junto a extremidade capitata (55\%) ou estende-se até o nível do corpo do epidídimo (45\%). Os mesmos autores citam que os feixes musculares junto a fáscia espermática são de natureza estriada esquelética, dispondose ora longitudinalmente e em ligeira espiral, ora claramente transversais, independentes do músculo cremáster.

O desenvolvido músculo cremáster encontrado nos tayassuídeos estudados provavelmente está relacionado com a termorregulação nas espécies, uma vez que a função deste é aproximar os testículos do corpo para manter, ou permitir diferenças na temperatura destes.

Outra estrutura testicular envolvida na termorregulação é a túnica albugínea (Setchell et al. 1994). Em alguns animais cita-se a presença de fibras musculares lisas dispostas por entre as fibras colágenas, como por exemplo nos suínos, eqüinos e ovinos (Chacon-Arellano \& Woolley 1980), porém pelas técnicas utilizadas neste estudo não nos foi possível identificá-las na albugínea de catetos e queixadas.

Segundo Setchell et al. (1994), as características estruturais da albugínea permitem que esta participe no transporte dos espermatozóides pelo seu provável papel na manutenção da pressão intersticial dentro do testículo. Os autores sugerem também um papel sobre o controle do fluxo sanguíneo testicular, uma vez que a artéria testicular e seus ramos mantém relação com a albugínea no estrato vascular.

A disposição profunda do estrato vascular encontrada neste trabalho nos catetos e queixadas também é descrita em garanhões e varrões, enquanto que em cães e carneiros este estrato é superficial (Banks 1992). A disposição dos vasos superficialmente ao testículo são mecanismos envolvidos na termorregulação testicular por promoverem possibilidades de trocas de temperatura sanguínea.

Com relação a disposição intraparenquimal da rede testicular, Setchell (1970), comenta que nos mamíferos prevalecem dois tipos: o superficial e o axial. A rede testicular superficial é encontrada em ratos, camundongos e hamsters, nestes é relativamente curta, localizada lateralmente próximo a extremidade capitata do testículo. Já a rede testicular axial é localizada centralmente no testículo, ocupa aproximadamente dois terços do comprimento deste e é encontrada no homem e em animais como porquinho da índia, coelho, macacos e em animais domésticos como cães, gatos, bovinos, ovinos e suínos, exceto nos eqüinos, animais em que a rede testicular é superficial. Como nestes animais anteriormente citados, nos resultados de testículos de catetos e queixadas a rede testicular é do tipo axial.

A disposição estrutural do parênquima testicular dos tayassuideos obedece a um padrão geral descrito para outros machos (Castro et al. 1997, Banks 1992, Setchell et al. 1994).

Nos animais jovens analisados os cordões testiculares ainda sem lúmen indicam um estágio imaturo do tecido testicular. Courot et al. (1970) descreve que as células somáticas ao longo da membrana basal dos túbulos seminíferos são encontradas de forma irregular, e nos animais jovens estas células ainda estão em um processo de diferenciação e são denominadas de células indiferenciadas de sustentação, as quais diminuem a medida que se aproxima a puberdade (Russel \& Griswold 1978). Nos cortes de testículo de queixada jovem isto é facilmente observado.

A disposição celular do epitélio germinativo que reveste os túbulos seminíferos encontrada em queixadas e catetos adultos é típica de atividade reprodutiva (Banks 1992, Setchell et al. 1994). Este epitélio é responsável pela produção dos espermatozóides (Junqueira \& Carneiro 1999), os quais se posicionam na luz dos túbulos quando estão sendo produzidos.

Antón et al. (1998) descrevem a presença de mastócitos no tecido testicular suíno, no entanto estes não foram observados nos testículos de catetos e queixadas, pelos métodos empregados.

Nos queixadas jovens observaram-se muitas células de Leydig entre os cordões testiculares e mesmo nos queixadas e catetos adultos estas foram observadas em grande quantidade. De um modo geral nos suínos as células de Leydig são abundantes (Banks 1992, Yazama et al. 1990), e, nestes e nos eqüinos, estas podem ocupar até 50\% do espaço intersticial, que por sua vez representa $40 \%$ do testículo (Setchell et al., 1994). Nos tayassuídeos, Paula \& Navarro (2001), trabalhando com adultos, descrevem que o espaço intertubular do testículo representa 15,8 $\pm 3,56 \%$ nos queixadas e $14,8 \pm 3,56 \%$ nos catetos.

As características histológicas das células de Leydig dos catetos e queixadas são também observadas nos suínos adultos e touros, em que se observam gotículas lipídicas que são eliminadas pelo processamento histológico, resultando em uma característica vesiculosa destas células (Banks 1992).

Particularmente nos suínos durante a puberdade há um aumento no tamanho e volume médios das células de Leydig, causado pelo incremento das organelas como mitocôndrias, lisossomos e gotículas lipídicas e um pico de hormônios esteróides produzidos por estas células. Após a puberdade ocorre um declínio no tamanho destas células (Lunstra et al. 1986).

Com relação os túbulos retos e eferentes as descrições em suínos (Orsi et al. 1986) assemelham-se com as encontradas nos catetos e queixadas de forma que a rede testicular consiste, de uma complicada rede de canais que 
se interconectam e que confluem para a extremidade cranial ou capitata do testículo. Em suínos é descrito que as células da rede testicular podem apresentar no pólo apical projeções globosas que foram interpretadas como atividade secretora apócrina (Banks 1992).

Por se tratarem de animais silvestres, principalmente nos criatórios extensivos, o manejo reprodutivo dos catetos e queixadas torna-se difícil e normalmente os lotes de animais destinados ao abate são heterogêneos, incluindo animais jovens e adultos.

Autores como Hellgren et al. (1989) citam haver diferenças morfológicas testiculares em grupos de catetos criados no Texas (USA) em diferentes fases do ano, como por exemplo variações no volume testicular e nas concentrações séricas de testosterona, com médias máximas no outono e inverno (1150-1400pg/ml). Os dados obtidos neste trabalho no entanto não fornecem subsídios suficientes para uma comparação efetiva se este fenômeno ocorre em catetos e queixadas criados em clima temperado, como é o caso do Estado de São Paulo.

As médias obtidas entre os testículos direito e esquerdo em catetos $(4,27 \mathrm{~cm}$ de comprimento e $2,71 \mathrm{~cm}$ de largura) podem ser consideradas semelhantes aquelas citadas também em catetos por Low (1970), para animais criados no Texas $(4,7 \mathrm{~cm}$ de comprimento e $3,30 \mathrm{~cm}$ para diâmetro); por Carvalhal et al. (2000) em catetos do Estado de São Paulo (4,5 cm para comprimento e 2,85 cm para largura) e por Hellgren et al. (1989) (4,9 cm de comprimento e 2,8 cm de largura). As mensurações biométricas para os queixadas descritas não possuem citações para comparações.

Paula \& Navarro (2001), estudando a taxa de produção espermática em 06 catetos e 06 queixadas adultos, descrevem ambas as espécies, possuem parâmetros biométricos testiculares muito semelhantes, como por exemplo o índice gonadossomático $(0,2 \%)$, o índice túbulossomático $(0,17 \%)$, e a relação de túbulos seminíferos dos testículos (84,\%), e este fato ocorre apesar da diferença no porte entre as duas espécies.

Os resultados para os testes de correlação de Pearson (r) altos e positivos entre os parâmetros analisados nos testículos são esperados, uma vez que os testículos são órgãos pares e apesar da variação encontrada normalmente não há grandes diferenças entre um órgão e outro. As correlações negativas entre o comprimento corporal e o comprimento dos testículos direito e esquerdo para queixadas adultos, provavelmente ocorre pelo fato de que mesmo que haja um aumento no tamanho corporal na fase adulta isso não necessariamente é acompanhado pelo aumento em comprimento dos testículos. Nos jovens no entanto esta correlação é positiva porque o ritmo de crescimento tanto do corpo quanto dos testículos é semelhante.

Os estudos sobre reprodutor masculino dos tayassuídeos possuem ainda muitos pontos a serem esclarecidos, para que assim a continuidade dos conhecimentos gerados possa preencher as lacunas ainda existentes nas diferentes áreas e desta forma contribuir efetivamente com a preservação destas espécies e auxiliar no desenvolvimento da exploração zootécnica das mesmas.

\section{Agradecimentos}

Ao Projeto BIOTA da Fundação de Amparo a Pesquisa de São Paulo, ao Centro de Multiplicação de Animais Silvestres da Escola Superior de Agricultura de Mossoró, RN e à Fazenda Devaneio-Pró-Fauna, Iguape-SP.

\section{Referências Bibliográficas}

ANDREA, M.V., OLIVEIRA, C., ROCHA, G.T. 2001. Cytogenetical and histological studies in testis of Tayassu tajacu (cateto), Tayassu pecari (queixada) and a natural interspecific hybrid. J. Anim. Brred. Genet. 118:125-133.

ANTON, F., MORALES, C., AGUILAR, R., BELLIDO, C., AGUILLAR, E. \& GAYTAN, F. 1998. A comparative study of mast cells and eosinophil leukocytes in the mammalian testis. J. Vet. Med. Series A, 45:209-18.

AYRES, M., AYRES JR, M., AYRES, D.L. \& SANTOS A.S. 2003. Bio Estat. Aplicações estatísticas nas áreas das Ciências Biológicas e Médicas. Belém: Sociedade Civil Maniraua, Brasília CNPq.

BANKS, W. J. 1992. Histologia veterinária aplicada. 2 ed. São Paulo: Manole.

BARONE, R. 1990. Anatomie comparée des mammifères domestiques. Splancnologie II. V. 4. Paris, Vigot.

CARROLL, R.L. 1988. Vertebrate paleontology and evolution. New York: W.H. Freeman \& Co. p. 507-17.

CARVALHAL, R., CAGNOTO, D.G. \& DANIEL, R.J. 2000. Aspectos morfológicos dos testículos e funículos espermáticos em catetos. Braz. J. Morphol. Sci., 17: 178. Suppl.

CASTRO, A.C.D., BERNEDSON, W.E. \& CARDOSO, F.M. 1997. Cinética e quantificação da espermatogênese: bases morfológicas e suas aplicações em estudos da reprodução de mamíferos. Rev. Bras. Reprod. An., 21: 25-34.

CHACON-ARELLANO, J.-T. \& WOOLLEY, D.M. 1980 Smooth muscle in the testicular capsule of the horse, pig and sheep. J. Anat., 131: 263-273.

COUROT, M., HOCHEREAUA-DE REVIERS, M.T. \& ORTAVANT, R. 1970. In: JOHNSON, A.D.; GOMES, W.R.; VANDERMARK, N.L. The testis. New York: Academic Press, V. 1, p. 339-431. 
DYCE, K.M.; SACK, W.O. \& WENSING C.J.G. 1997. Tratado de anatomia veterinária. 2ed. Rio de Janeiro, Guanabara Koogan.

HELLGRENT, E.C., LOCHMILLER, M.S.,AMOSS, JR. M.S., SEAGER, S.W.J., MAGYAR, S.J., COSCARELLI, K.P. \& GRANT, W.E. 1989. Seasonal variation in serum testorone, testicular measurements and semem characteristics in the collared peccary. J. Reprod. Fert., 85: 67786.

INTERNATIONAL COMMITTEE ON VETERINARY GROSS ANATOMICAL NOMENCLATURE. 1994. Nomina anatomica veterinaria, 4. ed. Ithaca, Word Association on Veterinary Anatomists. (Together with Nomina Histologica, 2. ed., 1992 and Nomica Embriologica Veterinary, 1992).

JUNQUEIRA, L. C. \& CARNEIRO, J. 1999. Histologia básica. 9 ed. Rio de Janeiro: Guanabara Koogan, p.427.

LOW, W.A. 1970. The influence of aridity on reproduction of the collared peccary [Dycotiles tajacu (Linnaeus)] in Texas. Vancouver, 1970. 170p. Doctoral Dissertation University of British Columbia.

LUNSTRA, D.D., FORD, J.J., CHRISTENSON, R.K. \& ALLRICH, R.D. 1986. Changes in Leydig cell ultrastructure and function during pubertal development in the boar. Biology of Reproduction, 34:145-58.

MACHADO, G. V., LESNAU, G. G. \& CARLESSO, T. 1997. Sobre a presença de musculatura estriada junto à fáscia espermática em catetos. CONBRAVET, outubro.

NOWAK, R.M. 1991. Walker's mammals of the world. 5 ed. London: Johns Hopkin Univ. Press.

OLIVEIRA, M.F., MACEDO, C.R., FEIJO, F.M.C., JUNIOR, R.A.B., CARVALHO, M.A.M., MENEZES, D.J.A. \& ASSIS NETO, A.C. 2001 Dados reprodutivos da criação de catetos em cativeiro no semi-árido nordestino (Tayassu tajacu). In Anais V Congresso e X Encontro da Associação Brasileira de Veterinários de Animais Selvagens). FMVZ-USP, SP. pp. 67.

ORSI, A.M., MELLO DIAS, S., SEULLNER, G., GUAZELLI FILHO, J. \& VICENTINI, C.A. 1987. Strucutre of the ductuli efferentes of the domestic pig (Sus scrofa domestica). Anat. Anz. Jena, 163:249-254.

PAULA, T.A.R. \& NAVARRO, R.D. 2001. Componentes testiculares de queixada (Tayassu pecari) e cateto (Tayassu tajacu). Rev. Bras. Rep. Ani., 25 (2): 206-207.

RUSSEL, L.D. \& GRISWOLD, M.D. 1978. The sertoli cell. London: Paul Elek, 450 p.

SANTOS, T.C., MIGLINO, M.A., MACHADO, G.V. \& SOUZA, W.M. 1999. Morfologia dos ovários, tubas uterinas e útero em catetos (Tayassu tajacu Linnaeus, 1758) e queixadas (Tayassu pecari Link 1795). Braz. J. Vet. Res. An. Sci., 33 (3):203-209.
SCHIMIDT, C.R 1988. Peccaries. In: GRZYMECK’S Encyclopedia of Mammals. New York, McGraw-Hill,V. 5.

SETCHELL, B.P. 1970. The secretion of fluid by the testis of rats, rams and goats, with some observations on the effects of age, cryptorchidism and hypophysectomy. J. Reprod. Fert. 23:79-83.

SETCHELL, B.P., MADDOCKS, M. \& BROOKS, D.E. 1994. Anatomy, vasculature, innervation, and fluids of the male reproduction tract. In: KNOBIL, E.; NEILL, J.N. The physiology of reproduction. 2 ed. New York: Raven Press, p. 1063-1175.

SOWLS, L.K. 1961. Gestation Period of the collared peccary. Journal of mammalogy, 42(3): 425-6.

SOWLS, L.K. 1984. The peccaries. Tucson, Univ. of Arizona Press.

THEIMER, T.C. \& KEIM, P. 1998. Phylogenetic relationships of peccaries based on mitochondrial cytochrome $b$ DNA sequences. J Mammal, 79:566-72.

VAUGHAN, T.A. 1978. Mammalogy. 3. ed. New York, Saunders College.

WISLOCKI, G.B. 1931. Notes on the female reproductive tract (ovaries, uterus and placenta) of the collared peccary (Peccary angulatus Bangsi Goldman). J. Mamm., 12:143-9.

YAZAMA, F., NISHIDA, T., KUROHMARU, M. \& HAYASHI, Y. 1990. A scanning electron microscopy of the interstitial tissue of the boar testis. Exp. An., 39(1):117-20.

Título: Aspectos Macroscópicos e Morfométricos dos Testículos em Catetos e Queixadas

Autores: Jussara Barreira Sonner; Maria Angélica Miglino; Tatiana Carlesso dos Santos; Roberto Carvalhal; Antônio Chaves de Assis Neto; Carlos Eduardo Bezerra de Moura; Moacir Franco de Oliveira.

Biota Neotropica, Vol.4 ( numero2): 2004

http://www.biotaneotropica.org.br/v4n2/pt/ abstract?article+BN03004022004

Recebido em: 08/03/2004 - Revisado em: 29/07/2004 Publicado em: 10/08/2004

ISSN 1676-0603 